Stellenbosch Theological Journal 2021, Vol 7, No 1, 1-39

DOI: http://dx.doi.org/10.17570/stj.2021.v7n1.a13

Online ISSN 2226-2385 | Print ISSN 0028-2006

2021 (c) Pieter de Waal Neethling Trust

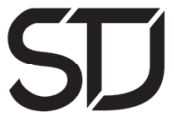

\title{
On politics of friendship
}

\author{
Dirk J Smit \\ Stellenbosch University \\ Stellenbosch, South Africa \\ Princeton Theological Seminary, NJ, USA \\ Extraordinary Professor of Systematic Theology \\ djs1@sun.ac.za
}

\begin{abstract}
The paper distinguishes four dominant discourses in contemporary so-called politics of friendship, namely a politics of enmity (Schmitt), a politics based on the notion of friends as "another self" (Aristotle), a politics of love (Augustine), and a politics of "perhaps" (Derrida). It then considers if and how Koopman's person and work fit into such a typology.
\end{abstract}

\section{Keywords}

Nico Koopman; friendship; politics of friendship; concept of the political; another self

\section{Person and work}

The invitation was for "a formal lecture that engages both Prof. Koopman's person and work." Normally, honouring someone's person and work

1 The essay formed the basis of a public online speech honouring Prof. Nico Koopman on the occasion of his $60^{\text {th }}$ birthday. The event to honour him was hosted by the Faculty of Theology of Stellenbosch University and the Beyers Naudé Centre for Public Theology, on 23 June 2021. Prof. Koopman is the Vice-Rector: Social Impact, Transformation and Personnel of Stellenbosch University, and formerly served as Dean of the Theology Faculty (2010-2015), Professor of Systematic Theology (Public Theology and Ethics, 2008-2010) and the first Director of the Beyers Naudé Centre (2002-2016).

My relationship with Prof. Koopman goes back a long way - he was my student at the University of the Western Cape; he approached me to supervise both his Master's thesis (on doctrine) and his doctoral dissertation (on ethics); he invited me to preach when he was installed in the ministry of the DRMC in Atlantis and again when he was later called as University Chaplain to the UWC; I responded to his inaugural lecture (on 
would involve both their professional careers, based on their curricula vitae - in his case a rich career in roles of minister, academic, administrator in tertiary education, community figure, public speaker, columnist and social media pastor - as well as their character and integrity, based on more personal knowledge.

In his case, that is not necessary or even possible, which is in itself remarkable. He hardly conforms to the usual distinction between private and public. In his institutional and professional roles he is simply true to himself and his convictions and commitments. To honour him, the best way may in fact be to try and understand why this is the case. What does his person and work invite, perhaps inspire, perhaps challenge, us to figure out?

The answer is obvious for anyone who knows him. He is committed to life in verbondenheid - difficult to translate, he even signs English emails like this. Our challenge is to consider what in verbondenheid means, where it originates, what his intentions may be, and where it may lead.

doing public theology) as professor at Stellenbosch University; I was chairperson of the Board of the Beyers Naudé Centre for Public Theology during the initial years while he served as Director; and I served with him as colleague and under him as Chair of the Department of Systematic Theology and Ecclesiology, as Dean of the Faculty of Theology, and as Vice-Rector of Stellenbosch University. Over the years, we supervised students together and collaborated in many research projects and ecumenical and academic networks, participated in the same consultations and conferences, and published in the same proceedings and volumes, even co-published papers on several occasions. He co-edited a Festschrift for me and edited a volume of my collected essays. I saw him represent the Faculty of Theology and Stellenbosch University on many occasions - and he often shared his South African marshmallows with me during lonesome international visits. 
For many years he signed almost all his correspondence with these words. ${ }^{2}$ He gave many papers ${ }^{3}$ and published many essays on togetherness. Most of his Godsdiens Aktueel columns in Die Burger return to togetherness. ${ }^{4}$

2 He usually signs with in verbondenheid, but sometimes also adds some qualification, based on the content of the particular correspondence, like in vreugdevolle verbondenheid (with good news), in tere (sometimes fragile) verbondenheid (with sad news), in waarderende verbondenheid, and recently very regularly, in saamstappende verbondenheid.

His most recent Godsdiens Aktueel column in Die Burger (9 June 2021) illustrates this once again very well. Under the heading "Sáám beur ons voort na 'n nuwe toekoms" he remembers "Oom Bey" (Beyers Naudé) and "sy vriend Nelson Mandela" and the new South African Constitution, "Daardie Grondwet stel as strewe 'n samelewing van menswaardigheid, geregtigheid, vryheid en gelykheid; 'n samelewing waar alle wonde genees word." Then he remembers a picture of "Oom Bey en Madiba," both old and frail and supporting one another, "om te midde van broosheid vorentoe te gaan het hulle mekaar nodig." He makes sure that his readers understand, "Hulle kan alleen vorentoe gaan as hulle saam vorentoe gaan." He then acknowledges that he likes to sign his correspondence with the words "in saamstappende verbondenheid" - and he explains the meaning and importance of the "saam," the together. In fact, he says, he still has the dream one day to write a small book with the title 'Together' - "Ek het nog die droom om eendag as ek groot is 'n boekie te skryf met die titel Saam." "Saam kan ons vorentoe gaan. Saam oorkom ons rassisme, klassisme, seksisme, homofobie en diskriminasie. Saam verwesenlik ons 'n samelewing van geregtigheid, vryheid en gelykheid. Covid-19, korrupsie, staatskaping, onbevoegdheid, middelmatigheid en ander bedreigings laat só 'n samelewing soos 'n hersenskim lyk. Die skynbare reuse wat ons bedreig laat ons broos voel. Maar saam beur ons vorentoe." This is his dream just the week before his 60th birthday and one that he seemingly has been dreaming for a very long time. It is hardly possible to underscore the importance of in verbondenheid for his self-understanding any clearer than this.

3 His curriculum vitae lists 70 papers at international consultations and conferences basically between 2001 and his appointment as Vice-Rector and they are rightly described as "mostly by invitation." The list clearly demonstrates how often he has been part of networks and how regularly he spoke on themes of in verbondenheid - broadly understood - in these international contexts. Many of these contributions were later published, in proceedings or in volumes. In fact, he was often a key figure in these networks, keeping them together simply through his personal friendship and presence - and he often persuaded some of us as his colleagues to participate as well, against our will, simply out of loyalty to him. The list of topics is in itself an extraordinary witness to his remarkable verbondenheid with many people in many and diverse contexts and in many parts of the world.

4 Even a superficial look at topics of his Godsdiens Aktueel column of the last years shows how regularly he writes about some form of in verbondenheid, almost like a refrain, in fact, it may be possible to claim that just about every one of these columns is about the same theme, from different perspectives - "Truth in many forms sets us free," "Striving together for light and justice" (honouring the memory of Danny Titus, but describing him in a way which could almost have been a self-description), "Get comfortable with a life full of contradictions," "Innovation and ingenuity can bring healing," "Excellence only possible through diversity," "Dance with hearts full of hope," "God's inclusive 
He even practices verbondenheid through daily prayers widely shared via social media. ${ }^{5}$

He is always searching for new conceptual tools with which to explain this verbondenheid - unity (as long as it is qualified by reconciliation and justice); ${ }^{6}$ Ubuntu (as long as it stresses shared life and interests); ${ }^{7}$ human dignity (as long as it speaks of universal respect) ${ }^{8}$ complexity; thinking

preferentiality brings salvation for us all," "Let us together imagine new ways to live," "Racism often hides in our subconscious," "Polarization will only hinder the Covid-19struggle," "Standing together brings hope in these vulnerable times," "Different faces of complexity" (titles translated).

5 He publishes daily prayers on social media (I think, based on what I have been told) and according to himself he receives responses and appreciation from far and wide. It has become like a form of ministry, a way of living in verbondenheid with many innumerable friends, known and unknown. I have had the remarkable experience during international consultations that the chairperson would open the first session of the day by reading in public "the prayer which Nico Koopman from Stellenbosch in South Africa posted this morning on his Facebook page."

6 He has always been very aware that any argument for unity should be carefully qualified. In this, the tradition of the Belhar Confession (1982/1986) clearly played an important role in shaping his thought, see e.g. Koopman, "Global Civil Society, Church Unity and World Unity", in William Storrar, Peter Casarella \& Paul Metzger (eds), A World for All? Global Civil Society in Political Theory and Trinitarian Theology (Grand Rapids: Eerdmans, 2011), 108-121; "Towards Reconciliation and Justice in South Africa. Can Church Unity Make a Difference?” in Sebastian Kim, Pauline Kollontai \& Greg Hoyland (eds), Peace and Reconciliation. In Search of Shared Identity (Burlington: Ashgate, 2008), 95-108; "Uniting for Unity, Reconciliation and Justice. The Uniting Reformed Church in Southern Africa," in Leo Koffeman (ed), The Protestant Church in The Netherlands: Church Unity in the 21st Century (Berlin: Lit Verlag, 2014), 100110; "Belhar: A Transforming and Dignifying Tradition." JTSA Vol 139 (2011): 32-41; "Reconciliation and the Confession of Belhar 1986. Some Challenges for the URCSA." NGTT Vol 48 (2007): 96-106.

7 See e.g. Koopman "Ubuntu is Not Enough. In Search of an Anthropology for Peaceful Living," in Dirk van Keulen \& Martien Brinkman (eds), Christian Faith and Violence. Studies in Reformed Theology Vol 10 (2005): 157- 171; “Trinitarian Anthropology, Ubuntu and Human Rights", in Russel Botman \& Karin Spörre (eds), Building a Human Rights Culture. South African and Swedish Perspectives (Falun: Stralins, 2003), 194-206; "Bonhoeffer's Anthropology and the Anthropology of Ubuntu," Nederlandse Theologische Tijdschrift (July 2005): 195-206.

8 See e.g. Koopman, "Theological Education for Dignity in Africa - a Public Theological Perspective," in Isabel Phiri \& Dietrich Werner (eds), Handbook of Theological Education in Africa (Geneva: WCC, 2013), 698-706; "Some Theological and Anthropological Perspectives on Human Dignity and Human Rights." Scriptura 95 (2007): 177-185; "Inclusive dignity and land reform in South Africa," Scriptura Vol 113 (2014): 1-8; "Towards the Fulfilment of Three Generations of Rights: A Theological Contribution by Koos Vorster." In die Skriflig Vol 46, no. 1 (2012), \#a.45; "Human Dignity in Africa: A Christological Approach," Scriptura, Vol 104, no. 6 (2013): 240-249; “Theology and 
en-en not óf-óf; compromise; hybridity; inclusivity; the common good; communion; solidarity; proximity; reciprocity; interpathy; wholeness, healing; embrace; togetherness; sáám and sáám-wees and sáám-stap and whatever else he may find. ${ }^{9}$

In fact, he expresses verbondenheid with more than words. Most are aware how he embodies verbondenheid through compassion, how unselfishly he spends energy and time, how often he can be found in hospital rooms and at funerals. Colleagues may be aware how, during conflicts, he reaches out to those of different opinion, inviting them for conversation, so that he may listen and perhaps learn how they think, and why. All this because he believes in verbondenheid. ${ }^{10}$

the Fulfilment of Social and Economic Rights," in André van der Walt (ed), Theories of Social and Economic Justice (Stellenbosch: Sun Press, 2005), 128-140; "Human Dignity, Human Rights and Socio-Economic Exclusion?," in Wilhelm Gräb \& Lars Charbonnier (eds), Religion and Human Rights. Global Challenges from Intercultural Perspectives (Berlin: De Gruyter, 2015), 131-148; "Men and Women in Church and Society. Equal in Dignity? United in Diversity?" in Elna Mouton, Gertrude Kapuma, Len Hansen \& Thomas Togom (eds), Living with Dignity: African Perspectives on Gender Equality (Stellenbosch: Sun Media, 2015), 19-32.

9 Sometimes he uses one of these terms, sometimes he lists many of them together, and over the years his lists kept getting longer and richer and more complex, to explain what in verbondenheid concretely means. See for the development and use of some of these notions e.g. Koopman "From Diverse and Apart to Diverse and Together. A Challenge of Rehumanization," in Eduardus van der Borght (ed), Affirming and Living with Differences, Studies in Reformed Theology Vol 12 (Leiden: Brill, 2006), 67-80; “Towards a Pedagogy of Hybridity, Reconciliation and Justice," in Brenda Leibowitz (ed), Higher Education for the Public Good (Stellenbosch: Sun Press, 2012), 151-163; "A Theology of Interpathy and Dignity," in James Cochrane, Elias Bongmba, Isabel Phiri, Des van der Water (eds), Living on the Edge. Essays in Honour of Steve de Gruchy (Pietermaritzburg: Cluster, 2013), 128-138; “Doing ethics in communion," NGTT Vol 48 (2007): 366-375; "Holiness and Public Life in South Africa: The Quest for Wholeness, Embrace and Justice." Colloquium 40, no. 2 (2008): 166-181; "Curing or Caring? Some Theological Comments about Healing," Religion and Theology Vol 13 (2006): 38-53; "An Active South African Civil Society for the Common Good, in Koos Vorster, Michael Welker \& Nico Koopman (eds), Church and Civil Society: German and South African Perspectives (Stellenbosch: Sun Press, 2017), 369-384; "The Common Good and Human Dignity - Some Very Preliminary Remarks," NGTT Vol 53, no. 2 (2012): 31-40; "Christian Baptism and an Identity of Inclusivity, Dignity and Holiness," in Eduardus van der Borght (ed), Christian Identity, Studies in Reformed Theology Vol 16 (Leiden: Brill, 2008), 120-13.

10 Others will probably also speak about this today, based on their own experiences of him in different contexts - of his curiosity and openness, his own vulnerability and teachability, his willingness to listen and his ability to learn, and probably much more. Vulnerability has increasingly played a key role in his anthropology and his understanding of verbondenheid, see e.g. Koopman, "On Leadership in Vulnerability," 
However, even deeper, one may perhaps claim that verbondenheid describes the way he thinks, his "habits of the mind." 11

He wrote his master's thesis in systematic theology on suffering, focusing on work by the Dutch theologian Bram van de Beek, who made use of paradigm theory to argue that there are different discourses about suffering in Biblical and Christian traditions. They are incommensurable, they cannot be reduced to one another or subsumed under one another, they exist together as legitimate ways - all of them speaking truth, but not so that these elements of truth can be integrated into one comprehensive theory, they can only function together, in verbondenheid. ${ }^{12}$

in Jeremy Punt \& Marius Nel (eds), Reading Writing Right: Essays presented in honour of Prof Elna Mouton (Stellenbosch: African Sun Media, 2018), 249-260; "Hope, Vulnerability and Disability? A Theological Perspective, in Julie Claassens, Leslie Swartz \& Len Hansen (eds), Searching for Dignity: Conversations on Human Dignity, Theology and Disability (Stellenbosch: Sun Press, 2013), 43-54; "Vulnerable Church in a Vulnerable World? Towards an Ecclesiology of Vulnerability." Journal of Reformed Theology Vol 2, no. 3 (2008): 240-254.

11 The reference is to Brian Gerrish's description of Reformed habits of the mind, in "Tradition in the Modern World: The Reformed Habit of the Mind," in David Willis \& Michael Welker (eds), Toward the Future of Reformed Theology. Tasks, Topics, Traditions (Grand Rapids: Eerdmans, 1999), 3-20.

12 Nico Koopman, God en die Lyding? ' $n$ Ondersoek na die Paradigma-Teorieë van A. van de Beek oor die Lydingsvraag (Bellville: University of the Western Cape, unpublished master's thesis, 1993). Professor Van de Beek later became an Extraordinary Professor of Systematic Theology at Stellenbosch and they became personal friends, collaborating in academic exchanges and scholarly networks. In his contribution to the Festschrift offered to Van de Beek, Strangers and Pilgrims on Earth, eds. Eduardus van der Borght \& Paul van Geest (Leiden: Brill, 2012), called "Public Theology in a Suffering World?," 887-895, Koopman, offers a remarkable defence of his friend Van de Beek against critique that he is not favourable towards public theology by appealing to Van de Beek's earlier work, as it were arguing that the later Van de Beek should be read in verbondenheid with - "through the lens of" - the earlier Van de Beek, and then his intentions and his own contribution to public theology will become clearer.

One of these networks of special importance in which they collaborated, was the socalled International Houten Conferences initiated by the Moluccan Theological Council with the Protestant Church of the Netherlands and including the Beyers Naudé Centre in addition to theologians from Ambon and other international contexts. In their Liber Amicorum celebrating ten years of these conferences, The Calling of the Church, eds. Lutzen Miedema \& Simon Ririhena (Stellenbosch: Sun Media, 2014), Koopman wrote one of his characteristic essays, that can almost serve as a self-description of how he understands in verbondenheid, called "Tasting the Communion of the Spirit? Reflections on a Decade-long Journey of Embrace," 91-101. The headings under which he tells this story of embrace already demonstrate his characteristic convictions and commitments - A Communion of Catholicity and Hybridity; A Communion of Unity 
He wrote his doctoral dissertation in theological ethics on the conflict between modern and postmodern approaches, using the renowned ethicists Harry Kuitert and Stanley Hauerwas as representatives of these seemingly mutually exclusive views. He once again argued that there are elements of truth in all these approaches and that they should all be taken seriously, together - probably to the surprise if not shock of both Kuitert and Hauerwas. ${ }^{13}$

Again and again this habit of the mind would show itself. His inaugural lecture argued for more than one approach to public theology - informed by a rich Trinitarian faith. ${ }^{14}$ The original purpose of the Beyers Naudé Centre for Public Theology was not to develop its own theology but rather to create spaces in a deeply divided society where opposing viewpoints could meet, including those who remained excluded from public discussions - so that all could be in one conversation, together. ${ }^{15}$ When he won the Andrew

in Search of Reconciliation and Justice; A Communion of Holiness and Civic Virtue; A Community of Apostolicity and Public Engagement.

In this essay he also makes use of the well-known and for him very important "I am an African"- speech by President Thabo Mbeki at the official adoption of the South African Constitution. Mbeki's words reflect, says Koopman, something of what he approvingly calls "a maximalist identity," "I owe my being to the Khoi and San. I am formed of the migrants who left Europe to find a new home on our native land. In my veins courses the blood of the Malay slaves who came from the East. I am the grandchild who lays flowers on the Boer graves on St. Helena and the Bahamas. I come of those who were transported from India and China. Being a part of all these people, and in the knowledge that none dare contest that assertion, I shall claim that - I am an African," 95. These words clearly capture much of what in verbondenheid means for Koopman.

13 Nico Koopman, Dade of Deugde? Implikasies vir Suid-Afrikaanse Kerke van ' $n$ ModernPostmoderne Debat oor die Moraliteit (Bellville: University of the Western Cape, unpublished dissertation, 2001). Over many years since then, he would regularly use the same methodological approach in most of his writings, appealing to many different sources, combining them in a constructive way into his own new argument as witnesses and authorities, although they often come from very diverse and sometimes even contradictory traditions and positions. This approach clearly illustrates the habits of his mind, namely seeing people and positions and persuasions as in verbondenheid with one another, although this may perhaps come as surprise to many of them. For him, they make sense together and they belong together.

14 Nico Koopman, "For God So Loved the World ... Some Contours for Public Theology in South Africa," Stellenbosch University: Inaugural Lectures, March 2009. This lecture is particularly instructive with a view to understand Koopman's own views concerning his thinking and task.

15 Koopman for example argues for the importance of such a spirit in his essays on implications from Bonhoeffer's life and work for public theology in South Africa, in "Bonhoeffer and the Future of Public Theology in South Africa. The Ongoing Quest for 
Murray Prize with Robert Vosloo, they argued for a variety of ethical approaches enriching one another in order to provide orientation. ${ }^{16} \mathrm{He}$ calls his own theology 'prophetic', but for him this no longer means one way of doing theology distinct from others, as normally understood, but rather as umbrella term including all those other ways from which prophetic theology has traditionally been distinguished. ${ }^{17} \mathrm{He}$ even treats his own social roles as being in verbondenheid - pastor, theologian, academic, administrator, it is often very hard to say which role he is performing when. All of this

Life Together," 85-96, and "Bonhoeffer in Harlem: Some Lessons for Contemporary South Africa," 151-162, in Robert Vosloo \& Nico Koopman, in Reading Bonhoeffer in South Africa after the Transition to Democracy: Selected Essays (Berlin: Peter Lang, 2020). Investigating possible lessons from Bonhoeffer's time in Harlem, he discerns three challenges for contemporary South Africa, namely the challenge to develop an ethic of interpathy, an ethic of hybridity and an ethic of special solidarity with the most vulnerable - all of these included in what he sees as in verbondenheid.

These original intentions behind the Beyers Naudé Center reflected something similar to the pathos of some so-called discourse ethicists like Karl-Otto Apel who argued for solidarity with those who are absent in our discussions, those strangers who are not present and cannot or are not allowed to speak for themselves; see Sander Griffioen \& René van Woudenberg, "We Must not Forget Those who are Absent. Interview with Karl-Otto Apel on the Universality of Ethics," in Sander Griffioen (ed.), What Right does Ethics have? Public Philosophy in a Pluralist Culture (Amsterdam: Vrije Universiteit Press, 1990), 11-21.

16 Nico Koopman \& Robert Vosloo, Die Ligtheid van die Lig. Morele Oriëntasie in ' $n$ Postmoderne Tyd (Wellington: Lux Verbi.BM, 2002).

17 The prophetic role of the church intrigued him from early on, but his understanding of the prophetic role changed over the years. Having encountered the way in which the Chicago ethicist James Gustafson distinguished between four moral discourses, namely prophetic-critical, technical-philosophical, narrative-formative, and policy or responsibility discourses, Koopman gradually suggested that all four these modes of ethics should be called prophetic. For someone in a position of responsibility, where one has to make and implement policy decisions within the parameters of what is realistically possible and in this process most probably has to make compromises, but someone who is still personally attracted to the prophetic role of the church, like himself, this is of course an attractive solution, but whether others will find it convincing and whether one can retain the critical edge of prophetic discourse is clearly another matter. For Koopman, see e.g. "Freedom of Religion and the Prophetic Role of the Church," NGTT Vol 43, no. 1 (2002): 237-247; "Let the Plight of the Poor be Heard. Prophetic Speaking about Poverty Today." NGTT Vol 45, no. 2 Supplementum (2004): 440-451; "Public Theology as Prophetic Theology. More than Utopianism and Criticism." JTSA Vol 134 (2009): 117-130; "Modes of Prophecy in a Democracy? in Heinrich Bedford-Strohm \& Etienne de Villiers (eds.), Prophetic Witness. An Appropriate Contemporary Mode of Public Discourse? (Berlin: Lit Verlag, 2011), 181-192; "Prophecy and Democracy? Some Arguments in Favour of Prophetic Discourse in Civilizing Democratic Societies," in Pieter Vos \& Onno Zijlstra (eds.), The Law of God. Exploring God and Civilization (Leiden: Brill, 2014), 239-255. 
reflects the same habit of the mind - he thinks in terms of togetherness, complementarity, mutually enriching verbondenheid.

But why? After all, this is not as obvious as one may think.

On a day like this, some idle speculation may even be allowed on where all this comes from - perhaps his personality, perhaps his formative childhood, family life and education, perhaps the spirit and culture of Niekerkshoop and Lime Acres and Kimberley and his beloved Northern Cape ${ }^{18}$ perhaps the shared experiences of Tokkies at UWC during those tumultuous years of "an injury to one is an injury to all"? ${ }^{19}$

However, we are also challenged to ask deeper questions, about what is known as the politics of friendship. Can and should friendship - notions of verbondenheid, solidarity, belonging, and shared life - indeed form the basis of public and political life, or not? Is it realistic to build our life in the

18 Koopman has a strong appreciation for ethical approaches based on moral formation, and character and virtues, on community and role models and examples. During the work on his doctoral dissertation he already developed the intellectual tools to deal with this, and in later years often wrote about this and propagated this in church and society as well, see e.g. his "Churches and Moral Formation in Public Life? The Story of the Ethical Leadership Project in the Western Cape.” Theologia Viatorum 37, no. 1 (2013): 108-122; “Towards a Human Rights Culture in South Africa. The Role of Moral Formation." NGTT Vol 48 (2007): 107-118. He therefore also has a strong appreciation of personal friendships, intimacy and familiarity and family life, compassion, and care, and indeed education and spiritual formation. When he had the opportunity to visit his alma mater, the William Pescod High School in Kimberley again, it was obviously a moving occasion for him.

19 The overwhelming experience when one reads the collection of contributions which students from the former Theology Faculty at the University of the Western Cape recently published to commemorate those years of study during the struggle, is one of such deep verbondenheid with one another. The volume is aptly called Tokkies. Reflections on Solidarity, with the moving subtitle Farewell to Unremembering: Commemorating the Faculty of Theology at The University of the Western Cape during the Struggle for Liberation, eds. Eugene Beukes, Andre Boezak, Nico Botha, Mariëte Frantz \& Derrick Marco (Belhar: LUS, 2020). The same spirit of solidarity and belonging is present in simply all the contributions. Nico Koopman also has an autobiographical contribution called "Formed by Peers, Pastors and Professors," 302-307, in which he reflects in detail how he was formed, already from his first year. From his fellow students, he says, "I found language for what my parents and role-models in the little towns where I grew up, taught me, but which they could not articulate in a sophisticated way." He concludes his deeply personal recollections with the acknowledgement that he honours the UWC and "I always belong to you" - once again the theme of verbondenheid. 
polis on such notions - and even if it is, would it be wise? These questions have always been deeply problematic, and they remain so today. ${ }^{20}$

Perhaps we may remind ourselves of four dominant discourses in today's politics of friendship to see potentially different meanings of the expression in verbondenheid - in order then to ask where Koopman belongs.

\section{"The concept of the political"?}

A first paradigm is the widespread view that political life should never be based on notions of verbondenheid and solidarity and friendship, because politics rests on the fundamental distinction between friend and enemy.

20 In Koopman's person and work it has always been clear that he does not make strict distinctions between private and public life and that his convictions have consequences for personal life, for the life of the church (in its several distinct social forms), for social and cultural life, and indeed for public and political life. This becomes evident from his understanding of public theology and from the seamless ways in which he can move from personal moral formation and life to ecclesiology to public policy and politics. Over the years he published extensively on the notion of public life, also while he was the Chairperson of the Global Network for Public Theology. From his many publications, see e.g. only "Public Theology in the Context of Nationalist Ideologies: A South African Example," in Sebastian Kim \& Katie Day (eds.) A Companion to Public Theology (Leiden: Brill, 2017), 150-163; "Public Theology in African Churches," in Isabel Apawo Phiri, Kennedy Owino, Dietrich Werner \& Chammah Judex Kaunda (eds.), Anthology of African Christianity (Oxford: Regnum, 2016), 1142-1148; "Public Theology and the Plight of Children in Africa," in Jan Grobbelaar \& Gert Breed (eds.) Welcoming Africa's Children - Theological and Ministry Perspectives (Durbanville: Aosis, 2016), 193-209; "In Search of a Transforming Public Theology: Drinking from the Wells of Black Theology," in Drew Smith, William Ackah, Anthony Reddie \& Rotney Tshaka (eds.) Contesting Post-Racialism. Conflicted Churches in the United States and South Africa (Jackson: University of Mississippi, 2015), 211-225; "Public Theology and the Public Role of Churches in South Africa today," in Allan Cole (ed.), Theology in Service to the Church (Eugene: Wipf \& Stock, 2014), 139-152; "Contemporary Public Theology in the United States and South Africa. A Dialogue," in Drew Smith (ed.), Freedom's Distant Shores. American Protestants and Post-Colonial Alliances with America (Texas: Baylor, 2006), 209-222; "Public Theology in South Africa," in Ernst Conradie \& Christo Lombard (eds), Discerning God's Justice in Church, Society and Academy (Stellenbosch: Sun Press, 2009), 69-80; "Public Theology in Pluralistic Societies?" Verbum et Ecclesia 33, no. 2 (2012); "Some Contours for Public Theology," International Journal of Practical Theology Vol 14, no. 1 (2010): 123-138; "Churches and Public Policy Discourses in South Africa." JTSA 136 (March 2010): 41-56; "Public Theology in South Africa. A Trinitarian Approach." International Journal for Public Theology Vol 1, no. 2 (2007): 188-209; "After Ten Years. Public Theology in Post-Apartheid South Africa." NGTT Vol 46 (2005): 149-164. 
Without enemies - opposition and contestation, conflict, and struggle there can be no political life, many argue.

This viewpoint was made influential by the German legal scholar Carl Schmitt. ${ }^{21}$ Our concept of the political, he argued, depends on the notion of the enemy. With only friends, political life is robbed and lost and becomes impossible. Today Schmitt is celebrated in both far right and far left circles. ${ }^{22}$ In both these traditions of reception, notions of democracy and recognition and solidarity and reconciliation are often suspect.

His argument rests on the distinction between private and public spheres. $\mathrm{He}$ is not talking about personal enemies or feelings of animosity. The words of Jesus to love our enemies do not refer to political enemies, he claims, ${ }^{23}$ but would this then mean that any signature of in verbondenheid remains strictly limited to the private sphere only, without public and political consequences?

21 His influential 1932 text has been translated and published in English by the University of Chicago Press, in 1966, again 2007, as Carl Schmitt, The Concept of the Political. Expanded Edition. The translation (by Georg Schwab) includes an instructive foreword by Tracy Strong and notes by Leo Strauss, but also the translation of another text by Schmitt from the same period, his 1929 essay on "The Age of Neutralizations and Depolitizations." Together, these pieces provide helpful insight in the major issues involved in Schmitt's understanding of "the concept of the political" itself, namely the relation between liberalism and democracy, the relation between politics and ethics, and the importance of the enemy. For an introduction into Schmitt's thought, see e.g. Heinrich Meier, The Lesson of Carl Schmitt. Expanded Edition (Chicago: The University of Chicago, 2011), and for even more detail, Reinhard Mehring, Carl Schmitt. Aufstieg und Fall. Eine Biographie (München: Verlag C.H. Beck, 2009).

22 Carl Schmitt has been a main figure in the rise of influential contemporary political theology, based on his well-known study called Political Theology. Four Chapters on the Concept of Sovereignty (Cambridge: MIT, 1985). For an instructive overview of how his ideas have been received in deeply contrasting ways in the USA, see e.g. Francis Schüssler Fiorenza, "Prospects for Political Theology in the Face of Contemporary Challenges," in Michael Welker (ed), Political Theology: Contemporary Challenges and Future Directions (Louisville: Westminster John Knox, 2013), 37-60.

23 In "the often quoted 'love your enemies' (Matt. 5:44; Luke 6:27)," he says, "no mention is made of the political enemy. Never in the thousand-year struggle between Christians and Moslems did it occur to a Christian to surrender rather than defend Europe out of love toward the Saracens or Turks. The enemy in the political sense need not be hated personally, and in the private sphere only does it make sense to love one's enemy, i.e. one's adversary. The Bible quotation certainly does not mean that one should love and support the enemies of one's own people." Schmitt, The Concept of the Political, 29. 
People participating in historical struggles - whether freedom struggles, class struggles, decolonization struggles, national, cultural, and ideological struggles - are often deeply critical and suspicious of talk about unity and reconciliation and verbondenheid since such talk often subverts their struggles. For them, "the agonistic political is the human ontological condition" - conflict and struggle and often war define the human condition and all political life $^{24}$ - remember our own struggles over reconciliation. ${ }^{25}$

The Cameroonian political theorist Achille Mbembe offers dramatic analyses of our world in this spirit in his Necropolitics, literally, the politics of death, although the original title is literally the politics of enmity. $\mathrm{He}$ describes what he calls the end of democracy and growth of societies of enemies. He paints a sombre, almost apocalyptic picture. Ours is a time of fear of others when people despise all and everything which are not from them and like them. It is a time of exclusion and new forms of apartheid. It is a time of borders and boundaries and walls. It is a time of brutality and without compassion, a time of longing for societies without strangers, a time of movements motivated by hate. Schmitt's world, Mbembe says, has become our world. ${ }^{26}$

24 The quote is from the Princeton theologian Mark L. Taylor's chapter "The Agonistic Political" in his The Theopolitical and the Political. On the Weight of the World (Minneapolis: Fortress, 2011), 67-114, but his whole book serves as authoritative voice for this kind of understanding of the political

25 The Kairos Document by the Institute of Contextual Theology remains one of the best known and powerful rejections of the notion of reconciliation in church and theology from the time of apartheid and the struggle. Two helpful resources that could perhaps still illustrate some of the conflicts and ideological misuses of the notion of reconciliation at the time are Willem S. Vorster (ed), Reconciliation and Construction (Pretoria; UNISA, 1986), and Klaus Nürnberger and John Tooke (eds), The Cost of Reconciliation in South Africa (Cape Town: Methodist Publishing House, 1988). Three more recent and helpful resources looking back and drawing on those conflicts are John de Gruchy, Reconciliation. Restoring Justice (Minneapolis: Fortress, 2002); Allan Boesak \& Curtiss Paul DeYoung, Radical Reconciliation. Beyond Political Pietism and Christian Quietism, (Maryknoll: Orbis, 2012); and Ernst Conradie (ed), Reconciliation. A Guiding Vision for South Africa? (Stellenbosch: EFSA, 2013).

26 Achille Mbembe, Necropolitics (Durham: Duke University, 2019), the argument of the whole book is relevant, but for Schmitt especially the chapters "The Society of Enmity" and "Necropolitics," particularly 48-52, 64, 70-78. The original title is Politiques de l'ininmitié and other translations are Een Politiek van Vijandschap and Politik der Feindschaft 
For this reason, many - e.g. the leading social commentator and scholar Tinyiko Maluleke - are sceptical of the notion of public theology and prefer not be called public theologians themselves because they prefer to underscore the particular struggles which sustain their theologies - Black, Liberation, African, Feminist, Political, and many others. In this spirit some argue that the role of power and widespread presence of violence and anger should be taken much more seriously than discourses of friendship and verbondenheid seem to allow. ${ }^{27}$

In such a world, the signature in verbondenheid can only mean that we are bound together to struggle, as enemies, bound together in political conflicts. Many indeed use the notion "bound together" in this way. They do not necessarily approve of enmity and conflict but acknowledge that this is the real world. In Bound to Differ the literary scholar Wesley Kort e.g. argued that differences and conflict are not accidental but central to theology itself and that without them "there would be little if any theology as we know it." ${ }^{28}$ Our differences make us who we are, our disagreements define us.

Similarly, the philosopher Kwame Anthony Appiah calls his work on identity politics The Lies that Bind. Rethinking Identity and then discusses

27 He makes clear that difference is a too innocent category to describe every reality from his African perspective, "Our differences are not only soft but hard, not (only) horizontal but vertical. It is not merely that some are men and others are women, but rather that men are gods and women their dispensable temptresses; not merely that some are white while others are black, but rather that whites are masters and the blacks are servants; not merely that some like wine while others like beer, but rather that some have much to eat and drink while others have nothing; not that some believe in hell and others believe in heaven but rather that some live already in heaven while others live already in hell." As result of that, "Some of the angriest people on earth, at this time in history, are to be found on the southern tip of the African continent ... This anger explodes in all sorts of ways ... Our language is violent, and violence is our language ... We are an angry people. This is an angry nation. Some of the angriest white as well as black people on earth live here. Some of the most violent people on earth are to be found here,” Tinyiko Maluleke, “The Elusive Public of Public Theology.” International Journal of Public Theology 5 (2011): 79-89; also Maluleke, "Why I am not a Public Theologian." Ecumenical Review Vol 72, no. 2 (2021): 297-315. For him and many others, public theology (depending on how it is defined and intended) is not able to deal with these realities of enmity and anger - some would argue that these theologies are too innocent, too universal, too silent about power, too elusive, too integrationist, too postmodern, too benign, romantic, civil.

28 Wesley Kort, Bound to Differ (University Park: Pennsylvania State University, 1992), ix 
creed, country, colour, class, and culture as the lies that bind us - always bind us to only some others, precisely while they simultaneously divide us from many other others. ${ }^{29}$ The political theorist Francis Fukuyama in Identity. The Demand for Dignity and the Politics of Resentment, similarly warns against the contemporary rise in identity politics, since "we will doom ourselves to continuing conflict." ${ }^{30}$ The philosopher Martha Nussbaum in the same spirit argues that "the cosmopolitan tradition" of sameness and togetherness is "a noble but flawed ideal." 31

Many more could be added but the first paradigm should be clear. According to many, it is naïve and misleadingly optimistic to build politics on friendship and verbondenheid. The reality is rather that we are bound to one another by power relations and injustice and violence.

\section{"Another self"?}

There is, however, also a second paradigm, equally widespread, namely the tradition that politics is indeed based on friendship. The classic authority has always been the Greek philosopher Aristotle, who explicitly argued for friendship as central foundation of ethics and politics ${ }^{32}$ - yet again, this tradition had many influential representatives over centuries. It is often regarded as the classic tradition of Western political philosophy, this politics of friendship. ${ }^{33}$

29 Kwame Anthony Appiah, The Lies that Bind. Rethinking Identity (London: Profile Books, 2018).

30 Francis Fukuyama, Identity. The Demand for Dignity and the Politics of Resentment (New York: Farrar, Straus, and Giroux, 2018).

31 Martha C. Nussbaum, The Cosmopolitan Tradition. A Noble but Flawed Ideal (Cambridge, Belknap, 2019).

32 Excerpts from two of his writings together provide the classical texts to study in this regard, namely his treatise on friendship in Books VIII and IX of the Nicomachean Ethics and a much briefer discussion of friendliness in II.4 of the Rhetoric. These two texts are often included in collections and overviews.

33 See e.g. the extremely helpful anthology of major texts throughout history by Michael Pakaluk, Other Selves. Philosophers on Friendship (Indianapolis: Hackett, 1991), as well as four important volumes with collections of essays on friendship, namely Leroy $\mathrm{S}$. Rouner (ed), The Changing Face of Friendship (Notre Dame: University of Notre Dame, 1994); Neera Kapur Badhwar (ed), Friendship. A Philosophical Reader (Ithaca: Cornell University, 1993); John von Heyking \& Richard Avramenko (eds), Friendship \& Politics. Essays in Political Thought (Notre Dame: University of Notre Dame, 2008); and Marco 
For Aristotle, a friend is just "another self" - distinguishing three forms of friendship - one based on utility, the usefulness of others, ways in which they provide what we need; one based on the pleasure others give us, the joys we share, the ways they attract and please and delight us; and one - for Aristotle the primary form of friendship - based on our common characters, values, convictions about truth and justice and goodness.

For him, all three these forms together contribute to social and public and civic life, they are all forms of political friendship, and - as many pointed out - they are all forms of self-love. ${ }^{34}$ We love our friends because we recognize something of ourselves in them - something that we need, enjoy or value. We actually love ourselves in and through them. ${ }^{35}$

The roots of many temptations are obvious to see. This form of verbondenheid easily only includes those who are like us and whom we like - from racisms to nationalisms to patriarchies to crude practices of favouritism and nepotism and corruption, we all know its many faces. ${ }^{36}$

Hofheinz, Frank Mathwig \& Matthias Zeindler (Hrsg.), Freundschaft. Zur Aktualität eines traditionsreichen Begriffs (Zürich: Theologischer Verlag, 2014).

34 In recent years, the notion of friendship has become increasingly popular in philosophical and especially Catholic theological and ethical circles, often studying Aristotle via Thomas Aquinas, and appreciating virtue and character ethics. For philosophical studies, see e.g. A.C. Grayling, Friendship (New Haven: Yale, 2013); Alexander Nehamas, On Friendship (New York: Basic Books, 2016); Richard Miller, Friends and Other Strangers. Studies in Religion, Ethics, and Culture (New York: Columbia University, 2016). For theological and ethical studies, see e.g. John P. Bequette, Christian Friendship. Engaging the Tradition, Transforming the Culture (Eugene: Cascade, 2019); earlier also David B. Burrell, Friendship and Ways to Truth (Notre Dame: University of Notre, 2000); Paul J. Wadell, Becoming Friends. Worship, Justice, and the Practice of Christian Friendship (Grand Rapids: Brazos, 2002), also his Friendship and the Moral Life (Notre Dame: University of Notre Dame, 1989); Gilbert C. Meilaender, Friendship. A Study in Theological Ethics (Notre Dame: University of Notre Dame, 1981); and Liz Carmichael, Friendship. Interpreting Christian Love (London: T \& T Clark, 2004), a study born in her experiences in South Africa. Nico Koopman often refers to others as friends and speaks about specific friendships, but he has not addressed the topic of friendship directly in any of his essays

35 The question whether self-love can be the basis of human relationships and in particular of public and political life has become very controversial, also in the reception of Aristotle and in ethical circles. For a discussion of one particular tradition in the South African context, see Dirk J. Smit, "On Self-love. Impulses from Calvin and Calvinism for Life in Society?" in Essays on Being Reformed. Collected Essays 3, ed. R R Vosloo (Stellenbosch: Sun Press, 2009), 493-512.

36 For nation and race as imaginative constructions of forms of verbondenheid, belonging, or not, see e.g. classical studies on nation like Benedict Anderson, Imagined 
This tradition took on many forms. Even Calvin argued that God gave something in others - even in those most different and furthest removed that we can recognize and respect, namely both God's own image which we all share and our own flesh. ${ }^{37}$ This formed the basis of his so-called social humanism. ${ }^{38}$

This tradition of "another self" would eventually contribute much to today's so-called universal values of human dignity and rights, to democratic culture, to liberal and humanist worldviews. This is the tradition heard in Koopman's inaugural lecture, when he says “when Nelson Mandela was released we faced the challenge to move from the old South Africa of diverse and apart to the new South Africa of diverse and together, from the old of enmity to the new of friendship, from the old of injustice to the new

Communities. Reflections on the Origin and Spread of Nationalism. Revised Edition (London: Verso, 2006); Ernest Gellner, Nations and Nationalism (Oxford: Blackwell, 1983); Eric Hobsbawm, Nations and Nationalism since 1780 (Cambridge: Cambridge University, 1990); and Adrian Hastings, The Construction of Nationhood. Ethnicity, Religion and Nationalism (Cambridge: Cambridge University, 2007); and classical studies on race like Francisco Bethencourt, Racisms. From the Crusades to the Twentieth Century (Princeton: Princeton University, 2013); Ibram X. Kendi, Stamped from the Beginning. The Definitive History of Racist Ideas in America (New York: Bold Type, 2016); Willie Jennings, The Christian Imagination. Theology and the Origins of Race (New Haven: Yale University, 2010); J. Kameron Carter, Race. A Theological Account (New York: Oxford University, 2008).

37 Discussing the commandment that we should not kill while he is explaining the Ten Commandments in Book II of the 1559 edition of the Institutes, Calvin e.g. argues: "(S) ince the Lord has bound the whole human race by a kind of unity, the safety of all ought to be considered as entrusted to each. In general, therefore, all violence and injustice, and every kind of harm from which our neighbour's body suffers, is prohibited. Accordingly, we are required faithfully to do what in us lies to defend the life of our neighbours, to promote whatever tends to their tranquillity, to be vigilant in warding off harm, and, when danger comes, to assist in removing it (Calvin, Institute II/8.39). Continuing, he motivates this by saying "Humanity is both the image of God and our flesh." Wherefore, if we would not violate the image of God, we must hold the human person sacred - if we would not divest ourselves of humanity, we must cherish our own flesh ... The Lord has pleased to direct our attention to these two natural considerations as inducements to watch over our neighbour's preservation - viz. to revere the divine image impressed upon them, and to embrace our own flesh" (Calvin, Institutes II/8.40, my italics). He very intentionally says that the implications of Jesus Christ for our verbondenheid with others will be discussed later, here he is still only concerned with "these two natural considerations".

38 See e.g. the authoritative studies by André Bieler, Calvin's economic and social thought (Geneva: WARC, 2006), and The Social Humanism of Calvin (John Knox, 1964). For Koopman's views on Calvin and public theology, see his "John Calvin, Holiness and Public Life in Africa.” NGTT Vol. 51 Supplementum (2010): 379-389. 
of justice for all, from the old of dehumanization to the new of dignity, from the old of racism to the new of nonracialism, from the old of classism to the new of equity and equilibrium, from the old of sexism to the new of gender justice and partnership, from the old of homophobia to the new of embracement of the other, from the old of ageism, handicappism and xenophobia to the new of hospitality to all age groups, to abled and differently abled people and to other nationalities, and from the old of ecocide to the new of communion and solidarity between the human and nonhuman parts of creation." ${ }^{39}$

Many of us will recognize this language as vintage Koopman - this is how he talks, this is how he writes, again and again, politically sensitive and correct and eager to include every new way in which verbondenheid and togetherness can replace apartheid and exclusion - and this clearly speaks the language of this long tradition of a politics of friendship. However, these two are not the only paradigms - and perhaps not yet the one he truly prefers.

\section{“There's somethin"?}

During the first centuries the Christian faith never really followed Aristotle and antiquity in this appreciation of friendship. Although the term "friend" also plays intriguing roles in Biblical traditions, ${ }^{40} \mathrm{Christians}$ disliked the problematic connotations of a politics of friendship, and preferred the terms neighbour instead of friend and love instead of friendship. ${ }^{41}$ For

39 "For God So Loved the World ... Some Contours for Public Theology in South Africa," Stellenbosch University: Inaugural Lectures, March 2009, 5; on democracy and citizenship, see also e.g. Koopman, "Citizenship in South Africa Today. Some Insights from Christian Ecclesiology." Missionalia Vol 43, no. 3 (2015): 425-437; "Theology and the Building of Civilising Democracy in South Africa.” NGTT Vol 55 (2014): 625-639.

40 See e.g. Douglas A. Hume, Virtuous Friends. The New Testament, Greco-Roman Friendship Language, and Contemporary Community (Eugene: Cascade, 2019).

41 See e.g. David Konstan, Friendship in the Classical World (Cambridge: Cambridge University Press, 1997). He paints a complex historical picture of major shifts in emphasis, from the bonding warriors in epic poetry, to the egalitarian ties of the Athenian democracy, the status-conscious connections in Rome and the Hellenistic kingdoms, until the commitment to a universal love among Christian writers. $\mathrm{He}$ concludes with an examination of how the ideas of brotherhood and universal love began to displace, at least in the writings of some Christians in the fourth century AD, 
Christians, love meant something different - something much more inclusive and radical. They were not concerned with being friends because I recognize myself in another, but with the love revealed in the One given for others while they were still enemies. ${ }^{42}$

In history, thinkers would often contrast the classical tradition of friendship with the Christian tradition of love, until the $19^{\text {th }}$ century Friedrich Nietzsche broke with both traditions, describing the Christian way as sick slave morality, and replaced both with the will to power. For Christians, this new verbondenheid founded in God's love of course raised the question who were include and who were excluded, often a real stumbling-block and scandal for the church.

Few expressed these Christian convictions more movingly than the Afrikaans poet Adam Small. In his first volume of poetry, Kitaar my Kruis

the classical ideas of friendship predicated on the mutual respect inspired by personal virtue.

42 There is a remarkable story about the Jewish scholar Jacob Taubes and Carl Schmitt. For many years, Taubes had been intrigued by Schmitt, in spite of his reputation. He admired his intellectual work. Over the years, there had been some incidental correspondence between them and when Schmitt was already ninety-one, Taubes wrote again. "Perhaps there will still come a moment at which we can speak about what is to me the most significant Jewish as well as Christian political theology, Romans 9-11," he wrote. "The word 'enemy' also appears there, but - and this seems to me to be the most decisive of decisive points - connected with "loved"” - loved by God. The next year, they finally found the opportunity to speak about these words. Taubes later told the story. He visited Schmittt at home. They went for a walk and when they came back, they were served tea, and Schmitt said: All right, Taubes, let's read Romans 9-11. It's one thing to read Romans 9-11 with theologians and philosophers, he said, and another thing with the greatest state law theorist of our time. Yet he explained Romans 9-11 to Schmitt, until Schmitt said, I did not know this, Taubes, before you die, you must tell some people about this - which is what he did, literally while he was dying, in his very last days, in the lectures that were posthumously published as The Political Theology of Paul. In making the distinction between friend and enemy so fundamental, Schmitt simply followed the centuries old way in which Paul had been misunderstood in the Christian tradition and in the church, said Taubes, he never understood that Paul spoke about enemy and love together in his doctrine of election, Taubes, The Political Theology of Paul (Stanford: Stanford University Press, 2004), 97-105, see 110-113.

wwFor thoughts on the development of altruism to include love for the enemy, see Dirk J. Smit, "Living with Strangers? On Constructing Ethical Discourses," in Daniel Pedersen \& Christopher Liley (eds.), Human Origins and the Image of God: Essays in Honour of J. Wentzel van Huyssteen (Grand Rapids: Eerdmans, 2017), 273-313. 
(1962), he has a poem called “There's Somethin'”"43 He addresses someone as "you" - obviously apartheid personified - and acknowledges how many things, normal, everyday, human things this "you" can stop him from doing. These many "silly things" that he can be denied evidently serve as description of the oppressive effects of the racist apartheid ideology and laws. Repeatedly, however, a refrain claims "but o there's somethin' you can never never do." "You” can even stop me ... "tryin' gettin' to Heaven from a Groote Kerk pew," but "there's somethin' you can never never do" - which is then revealed in the last lines, namely "you can't ever ever stop me loving even you!"

This was already the political tradition of the major North African thinker from the $4^{\text {th }}$ century, Augustine, who prayed to God in his influential Confessiones, "Blessed are those who love you, and love their friends in you and their enemies for your sake." ${ }^{44}$ Loving friends in God and loving

43 Adam Small, Kitaar My Kruis (Kaapstad: HAUM, 1974), 55-56. In another poem from the same volume, the deeply satirical "Eksegese 1," there is an ongoing argument between the prophets Elijah ("die man met die ligte vel") and Elisha. Elijah tries everything to persuade Elisha to stay, so that he could separate himself and follow God's call on his own, alone, to Bet-El, but Elisha stubbornly refuses saying, "sowaar die Here leef ... ek verlaat jou nie." Elijah is convinced, "nou moet ons uit mekaar uit gaan//die Here wil hê ons moet mekaar laat staan//die Here roep my alleen na die Jordaan" - but, "Elisa wou nie weg nie, Elisa wou nie skei//Elisa het soos 'n skadu op sy spoor gebly." Then, in Small's powerful satire, there is a turn of events. The Lordself intervenes and from a storm sends horses with a wagon to separate Elijah from the stubborn Elisha, "toe word die Here self vir Elisa boos// - want die Here is met sy eie, bars of breek//die Here laat Sy eie nooit in die steek." Remembering the often tragic and terrible history of the Christian faith and church, the final words strike deep, "Elisa het na sy donker vel gekyk//en verleë deur die donker weggestryk," 30-31

44 "Beatus qui amat te et amicum in te et inimicum propter te," Augustine, Confessiones, IV, IX, 14. On friendship in Augustine, see e.g. Donald X. Burt, Friendship and Society. An Introduction to Augustine's Practical Philosophy (Grand Rapids: Eerdmans, 1999). He claims that at the root of Augustine's practical philosophy is the love of friendship which obviously leads to the many fascinating ethical and political questions regarding Augustine's influence occupying scholars until today.

Augustine changed the popular definition of a state by Cicero to argue that "a state is an assemblage of reasonable beings bound together by a common agreement concerning the objects of their love." The implications of this would be far-reaching and dramatic. This means that our shared identities are to be found in our shared loves, in our common verbondenhede. People belong together who share common objects of love. In contemporary political theology this conviction would become extremely popular and influential. A well-known example is the work of the Regius Professor of Moral Theology in Oxford, Oliver O'Donovan. He explained this position already in his study called The Desire of the Nations. Rediscovering the Roots of Political Theology 
enemies for God's sake - this clearly had different social and political implications.

Koopman's appreciation for Adam Small is well documented, and the title of his inaugural lecture unmistakably reflects the spirit of Augustine, "For God So Loved the World ... Some Contours for Public Theology in South Africa." 45

In the New Testament, this spirit is abundantly clear, as in the parable of the Good Samaritan. It begins with a question in the spirit of our first

(Cambridge: Cambridge University, 1999), and developed it further in his analysis of the relationship between politics and theology called The Ways of Judgment (Grand Rapids: Eerdmans, 2005). O'Donovan learnt the foundations of his own political theology from Augustine already when he worked on his own dissertation called The Problem of Self-Love in Augustine (New Haven: Yale, 1980), a period of ten years during which "he lived with, thought, prayed, preached, and taught with Augustine," he later said, a period "which became a life-shaping experience for him." He would again later use Augustine's insights into the importance of our loves in forming our lives in his Common Objects of Love. Moral Reflection and the Shaping of Community (Grand Rapids: Eerdmans, 2002). Our shared identities and our social and political life reflect "our elementary knowledge of the world as a kind of love," he says, quoting Augustine's definition of a people as "a gathered multitude of rational beings united by agreeing to share the things they love." In Bonds of Imperfection. Christian Politics Past and Present (Grand Rapids: Eerdmans, 2004), written with his wife, Joan Lockwood O'Donovan, he drew out the practical implications of Augustine's political thought in The City of God, saying that, if our political realities today "do not trouble us" or "if we think that there are alternative patterns of political life available which are not vulnerable to treachery, stupidity, or simple conflicts of view, then we will find Augustine's sombre rhetoric merely perplexing" and we will "shake our heads in bewilderment and ask, 'But why was he so gloomy?'” If, however, we do see the dark side of our common life and we do agree that there are hardly any alternative patterns available not facing similar temptations, we will appreciate Augustine's insights into the crucial importance of our verbondenheid for our public and political life.

Hannah Arendt of course also wrote her doctoral dissertation on Augustine's understanding of love, published as Love and Saint Augustine (Chicago: University of Chicago, 1996), and she is also an inspiring figure in the contemporary discourse on a politics of friendship, see e.g. Jon Nixon, Hannah Arendt and the Politics of Friendship (London: Bloomsbury, 2015), in which he analyses four of her major friendships with a view to their diverse constructive contributions to her thoughts about the politics of friendship, and concludes that the key categories in her thinking about politics were "plurality" and "promise" - exactly the same two categories that are at the base of Koopman's views on verbondenheid.

45 For Koopman on Small, see e.g. "A Prophet for Dignity? A Theological Perspective." Tydskrifvir Letterkunde Vol 49, no. 1 (2012): 5-15; also "Adam Small se Transformerende Afrikaans," in Wannie Carstens \& Michael le Cordeur (eds), Ons Kom van Vêr: Bydraes oor Bruin Afrikaanssprekendes se Rol in die Ontwikkeling van Afrikaans (Tygervallei: Naledi, 2016), 539-551. 
two paradigms, Who may I exclude from any verbondenheid and regard as enemy, and who is my neighbour? Replying, Jesus deliberately uses a Samaritan as example, the classic figure of the political enemy, the furthest apart and most different imaginable. Go and do likewise, Jesus concludes, after the account of an attack on a dangerous road. Do not ask who my neighbour is, but go and become a neighbour, a friend, precisely to those publicly regarded as your enemies. ${ }^{46}$

46 Discussing the tenth commandment in Book II of the Institutes, Calvin e.g. refers to the Good Samaritan and claims "Our Saviour having shown that the term neighbour comprehends the most remote stranger, there is no reason for limiting the precept of love to our own connections. The whole human race, without exception, are to be embraced with one feeling of charity: that here there is no distinction of Greek or Barbarian, worthy or unworthy, friend or foe, since all are to be viewed not in themselves, but in God. If we turn from this view, there is no wonder that we entangle ourselves in error. Wherefore, if we would hold the true course in love, our first step must be to turn the eyes not to human beings, the sight of which might oftener produce hatred than love, but to God, who require that the love we owe to him be diffused among all humankind, so that our fundamental principle must ever be, Let a person be who they may, they are still to be loved, because God is loved" (Calvin, Institutes II/8.55).

When he offers his well-known and influential description of the Christian life in Book III of the Institutes, he seems very aware that his readers may refuse to acknowledge their verbondenheid with some people who do not seem to qualify as "another self" because of their behaviour towards us, and he enters into detailed rejections of these imagined objections, saying "The Lord enjoins us to do good to all without exception, though the greater part, if estimated by their own merit, are most unworthy of it. But Scripture subjoins a most excellent reason, when it tells us that we are not to look at what people in themselves deserve, but to attend to the image of God, which exists in all, and to which we owe all honour and love. Therefore, whoever be the person that is presented to you as needing your assistance, you have no ground for declining to give it to him or her. Say it is a stranger. The Lord has given that person a mark which ought to be familiar to you: for which reason he forbids you to despise your own flesh (Gal. 6:10). Say the person is mean and of no consideration. The Lord points him or her out as one whom he has distinguished by the lustre of his own image (Isaiah 58:7). Say that you are bound to that person by no ties of duty. The Lord has substituted him as it were into his or her own place, that in that person you may recognize the many great obligations under which the Lord has laid you to himself. Say that the person is unworthy of your least exertion on his or her account; but the image of God, by which that person is recommended to you, is worthy of yourself and all your exertions. But if the person not only merits no good, but has provoked you by injury and mischief, still this is no good reason why you should not embrace him or her in love and visit them with offices of love. That person has deserved very differently from me, you will say. In this way only we attain to what is not to say difficult, but altogether against nature, to love those that hate us, render good for evil, and blessing for cursing, remembering that we are not to reflect on the wickedness of people, but to look to the image of God in them, an image which, covering and obliterating their faults, should by its beauty and dignity allure us to love and embrace them" (Calvin, Institutes III/7.6). 
Signing emails in the spirit of this paradigm with in verbondenheid would say nothing about the person addressed and not even something about any already existing relationship, but primarily something about the one signing. It says I feel bound to you and am committed to you - for God's sake - irrespective of how you may feel about me and of any histories between us.

This way of thinking obviously raises new and challenging questions also for public life and politics. Allan Boesak is well-known for his moving expositions of this parable. The final question, he often says, is what the Good Samaritan was supposed to have done if he appeared on the scene while the attack was still taking place? - since this is after all where we find ourselves implicated in the struggles of life. ${ }^{47}$

\section{"Perhaps"?}

For this reason one may also distinguish a fourth discourse, namely the critical, sceptical, even cynical thinking of figures like Nietzsche and Derrida. Derrida's study called Politics of Friendship appeals to a long tradition who all preferred another quote attributed to Aristotle, although

Calvin's sermons similarly abound with observations in this spirit, for example "As long as we are human, we cannot but behold our own face as it were in a glass in people who are poor and despised, though they were the furthest strangers in the world. Let a Moor or a Barbarian come among us, and inasmuch as they are human, they bring with them a looking glass wherein we may see that they are our brothers and sisters and neighbours" (Calvin, Sermon on Gal 6:9-11).

On the Good Samaritan, see the essay by Frits de Lange, "The Event of Compassion," in Frits de Lange \& Juliana Claassens (eds), Considering Compassion. Global Ethics, Human Dignity, and the Compassionate God (Eugene: Pickwick, 2018), 17-30. This volume is the proceedings of one of the joined consultations between the Protestant University of the Netherlands and the Faculty of Theology at Stellenbosch, and De Lange and Koopman together were the two figures and friends who led and inspired this process over many years.

47 See e.g. Allan Boesak, "Combative Love and Revolutionary Neighbourliness: Kairos, Solidarity, and the Jericho Road," Kairos, Crisis, and Global Apartheid. The Challenge to Prophetic Resistance (New York: Palgrave Macmillan, 2015), 169-197; also Dirk J. Smit, "Justice as/and Compassion? On the Good Samaritan and Political Theology," in Claassens \& De Lange, Considering Compassion, 109-128, with further references to Boesak. 
no-one knows whether he actually ever said that. ${ }^{48}$ These words which Aristotle perhaps, but perhaps not, used, are, literally, "O friends, no friend." It is in the literary form of an apostrophe, addressed to someone (called friends, in the plural), but we do not know to whom or what it means. This allows Derrida - as is typical - to suggest different contexts in which these words could have been said, each time also translated differently, with different meanings. ${ }^{49}$

In ten dense chapters he plays this same game, each time beginning with these words, yet each time imagining different contexts and different meanings with different implications. ${ }^{50}$ Although impossible - and probably

48 Jacques Derrida, Politics of Friendship (London: Verso, 1997). The book was based on a series of twelve seminars which he gave during 1988-1989. From Nietzsche he deals in particular with his Human All Too Human, A Book for Free Spirits (from 1878), the first in a trilogy and the first book in which Nietzsche made use of aphorisms, but also the book in which Nietzsche deliberately turned these words from Aristotle upside down in an aphorism which Derrida analyses and deconstructs in the finest of detail and almost word by word, "Perhaps to each of us there will come the more joyful hour when we exclaim: 'Friends, there are no friends!' thus said the dying sage; 'Foes, there are no foes! Say I, the living fool" (Derrida's italics). Derrida comments, amongst others, "What are we doing and who are we, we who are calling you to share, to participate and to resemble? We are first of all, as friends, friends of the solitude, and we are calling on you to share what cannot be shared: solitude. We are friends of an entirely different kind, inaccessible friends, friends who are alone because they are incomparable and without common measure, reciprocity, or equality. Therefore, without a horizon of recognition. Without the familial bond, without proximity, without oikeiótes" (oikeiótes means kinship, belonging, claiming as one's own, therefore literally verbondenheid). This is amongst others - why there is no friend, for Nietzsche. True friendship is impossible. There is no real "brotherhood" (Derrida exposes the gendered, exclusive and oppressive nature of this tradition and discourse in detail), there is no real recognition, there is no real proximity, there is no real friendship, even and precisely when we use these words. We only cover up the secret of our solitude. Of course, terms like proximity and recognition and reciprocity have been central in the thought of Koopman and some of his colleagues, including Robert Vosloo (with cutting-edge work on recognition)

49 It can be translated in several different ways, it could even have been spelled differently, since the original Greek diacritical marks are omitted. For an extremely detailed and useful overview of the history of reception of these words, access on Aphelis. An Iconographic and Text Archive related to Communication, Technology and Art, the long discussion under https://aphelis.net/o-friends-there-are-no-friends-aristotle

50 It is tempting to continue and play the game by oneself. The expression could, for example, be words commemorating the death of someone, and therefore mean, My friends, our friend is no more, with the implication that all friendship brings sadness and loss and mourning and the knowledge that this will not last. Or it could, for example, mean, Oh, all those who claim to have many friends do not really have one true friend, since friendship takes much time to develop. It could mean that many may be called friends, but no-one truly is which would raise normative questions about 
sacrilegious - to attempt to say what Derrida means, there is a theme running through his Politics of Friendship, namely the theme of perhaps, of the future, of the not yet. ${ }^{51} \mathrm{Oh}$, my friends, there is no true friend. We know secretly that whenever we say friendship, we are actually covering up much darkness. We know there is no real verbondenheid, solidarity, democracy. Yet, perhaps? After all, every time we testify that "there is no friend," do our words not sound like a sigh, a longing, hope, promise, that one day, in future, perhaps ...? After all, why do we say this, why do we sigh like this, to one another? Because we secretly long that things were different and that there were friends? And by longing together like this, do we perhaps somehow - promise one another something? Do we with our sighs together wonder whether things may - perhaps, perhaps - become different, after all?

This "possibility of this impossibility" should always remain, he says, this remote possibility of the impossibility of real friendship, belonging, recognition, sáám-wees, verbondenheid, this is decisive for our future. Sighing like this, signing our name like this, is a risk, Derrida says, full of "uncertainty," filled with "the inassurance of the 'perhaps", yet, it is living "with an open heart." "Friendship with an open heart" is living as if things may become different after all - perhaps. ${ }^{52}$

He concludes the book with self-critical questions. In his own special way, he says, he also believes and keeps wondering whether it is possible "to think and to implement democracy"? Could we still use the old names but uproot them from the dark meanings they acquired for so long, imagining

friendship and what it could really mean. It could mean that among many friends there is no true friend which makes us wary and distrustful of all those who claim to be and pretend to be and seem to be friends. It could mean that in public and political life one should not look for friends because friendship can never form the basis for life together with all and everyone in the public sphere. Etcetera.

51 Derrida's work in fact can be read as a direct response to Schmitt's distinction between friend and enemy as the foundation of the political, but the only alternative that he offers seems to be the possibility of "perhaps."

52 Derrida, "Loving in Friendship: Perhaps - the Noun and the Adverb," in Politics of Friendship, 26-48. 
something new, perhaps? ${ }^{53}$ His final line reads "O my democratic friends ..." Does it not sound almost like the signature "in verbondenheid"? ${ }^{54}$

\section{"In verbondenheid"?}

So, where do we find Koopman in this typology? What does his signature in verbondenheid share ${ }^{55}$ Remembering his habits of the mind we should probably expect to find him agreeing with elements of truth in all four paradigms. Yet all four are dangerous - they can all tempt and mislead and have often done that in the past. All four are therefore contested. There is no way to sign them and expect that all others will appreciate and agree. Many will inevitably be suspicious - and often critical, whatever one may mean.

There is no way in which Koopman would support the politics of enmity of Schmitt, in fact, his deepest passion has always been to oppose such forms of seeing others as different and therefore enemies - but, hopefully, he is realistic enough to see the seriousness of all this, to see the kind of world that Mbembe so movingly describes, and to realize that for the moment we may indeed only be bound to many others by the lies that we are continuously made to believe - we about them, they about us.

53 Derrida, "For the First Time in the History of Humanity," in Politics of Friendship, 271-308.

54 Derrida, Politics of Friendship, 306.

55 It is indeed significant that Koopman actually signs his emails and letters with in verbondenheid, that he intentionally makes it a very visible part of his signature. For several political theologians like Agamben and Derrida himself the notion of the signature is of key importance, amongst others as a moment, an event, of the revelation of identity. Agamben e.g. wrote a treatise called The Signature of All Things, Derrida wrote an essay called "Signature Event Context" and a well-known introduction to Derrida is called Signature Derrida, ed. Jay Williams (Chicago: University of Chicago Press, 2013). For Derrida it is therefore of great importance that these words of Aristotle are in the form of an apostrophe or direct address, thus spoken by a specific speaker addressed to a specific audience. Using in verbondenheid like that, Koopman is not merely writing "about" verbondenheid, like a scholar or pastor or columnist about a topic, but he is actually performing, he is committing himself personally with those words and committing himself again and again, in a new event every time, in every new conscious decision to use that signature once again, in this email, to this person, almost like a promise to be trusted. 
There can also be no doubt that he is deeply committed to the second paradigm - to the tradition of Aristotle and to liberal, humanist, democratic values and institutions and practices, to deep-seated convictions concerning human dignity and rights, tolerance and radical inclusivity and equality and justice, well-being and flourishing. These are all Koopman words. When he signs with in verbondenheid he most probably also implies that his addressee is somehow just another self - trusting that they do share something in common, whether needs or joys or values, that somewhere deep they do belong together, in spite of outward appearances and inner feelings?

However, he most certainly also believes in the third way of the Christian tradition. In fact, here he may be most at home. His in verbondenheid probably says more about himself than about his addressees. He is probably saying, I am committed to you - irrespective of how you may feel about me. Our friendship does not depend on something in you and in you being a friend to me, but on something in me and on me intending to be a friend to you, no matter what. ${ }^{56}$

And again, as with the other discourses, it is obvious why this spirit will meet with refusal and resistance and rejection by many. All these discourses have dark and dangerous histories. But what about the fourth one? We should hopefully also hear this in his words. Again, some may doubt that. They may find him too positive and approving and enthusiastic, not prophetic enough in the traditional sense, not sceptical and critical enough, often showing too much gratitude and too little struggle - but this is probably a grave misreading of his intentions and signature. ${ }^{57}$

56 It is most probably this spirit, which may also be the way in which he understands Augustine, Calvin, Desmond Tutu, Beyers Naudé, Nelson Mandela, that he wishes to express. Examples of his appreciation for all these figures could easily be documented, see e.g. for Beyers Naudé his "This is Who He is! Beyers Naudé - A Man of Virtue and Character," in Len Hansen (ed), The Legacy of Beyers Naudé (Stellenbosch: Sun Press, 2005), 153-168

57 Although this impression may indeed sometimes be created by his obvious enthusiasm and support for a democratic South Africa based on human dignity and rights, and even by his loyalty to the University of Stellenbosch, including the responsibilities and initiatives of his own position, he made this critical awareness for example explicit in a recent essay, Koopman, "Envision and Criticize: Doing Public Theology When Democracy Seems to Fail." International Journal of Public Theology Vol 13, no. 1 (2019): 94-108. 
Read carefully, Koopman is not merely endorsing and defending existing realities - whether church, university, democracy, or constitution although it may sometimes almost seem to be the case. Read carefully, he in fact seems to be committed to what these institutions could be - but not yet are. He rather seems committed to the "perhaps" of a politics of friendship, to the future and what could perhaps become real, if we commit ourselves together to this imagination..$^{58}$ When he signs with in verbondenheid, he probably means, I trust that you are also committed to this dream of what is not yet real. $\mathrm{O}$ friends, I know there is no friend - there is no democracy, yet; there is no justice, yet; there is no inclusion and equality, yet; there is no well-being and transformation, yet; but hopefully you also still share this dream?

The best indication that this may be his intention may lie in the role that prayer plays in his thought. This is indeed remarkable. Here we celebrate a public intellectual and vice-rector of a university who openly and regularly speaks about prayer and worship, and in fact practices a daily ministry of public prayer. Why?

Perhaps his small work with Reflections on the Lord's Prayer, called Cries for a Humane Life provides an answer. He introduces the Lord's Prayer as "a cry to belong" - and then discusses the petitions all from this remarkable perspective..$^{59}$ In his own way, Koopman's logic reminds us of the logic of another friend, who also lived "as if not" and also imagined a different

58 The recent example of his Godsdiens Aktueel column quoted earlier e.g. makes this very clear - there are giants that threaten us and only together can we move forward - but if one reads closely, then this seems to be the tone of most of these pieces in Die Burger. Further examples could easily be multiplied, when read carefully. They are not merely an attempt to justify any institutional and public realities, but they serve on a deeper level as calls to shared commitment to a vision of difference amidst togetherness over against all visions and calls for apartheid, separation, division, and mutual rejection. The latter vision without doubt forms the dark background of "never again" from which he came - and where he does not wish anyone to return.

59 Nico Koopman, Cries for a Humane Life. Reflections on the Lord's Prayer (Wellington: Bible Media, 2014). This understanding of prayer is of course central to the Reformed tradition, for example as found in John Calvin, the Heidelberg Catechism and Karl Barth. For ways in which Koopman thinks prayer and public life together, see also his earlier "Prayer and the Transformation of Public Life in South Africa." Interpretation Vol 68, no. 1 (2014): 54-65; and already "The Lord's Prayer - An Agenda for Christian Living." Journal for Reformed Theology Vol 1, no. 3 (2007): 1-4. 
future. ${ }^{60}$ The Lord's Prayer for him serves as the cry for political friendship not yet fulfilled, but perhaps.

So, what does his person and work make us think about on his $60^{\text {th }}$ birthday? Perhaps we should think about prayer - as expression of human cries for belonging, for life in verbondenheid, prayer as "thinking our way into God's world," ${ }^{61}$ prayer as politics of friendship.

\section{Bibliography}

Anderson, Benedict, Imagined Communities. Reflections on the Origin and Spread of Nationalism. Revised Edition (London: Verso, 2006).

Arendt, Hannah, Love and Saint Augustine (Chicago: University of Chicago, 1996).

Appiah, Kwame Anthony, The Lies that Bind. Rethinking Identity (London: Profile Books, 2018).

Badhwar, Neera Kapur (ed), Friendship. A Philosophical Reader (Ithaca: Cornell University, 1993)

Bequette, John P., Christian Friendship. Engaging the Tradition, Transforming the Culture (Eugene: Cascade, 2019).

Bethencourt, Francisco, Racisms. From the Crusades to the Twentieth Century (Princeton: Princeton University, 2013).

60 See Albert Grundlingh, Ruda Landman \& Nico Koopman (eds), Russel Botman. A Tribute 1953-2014 (Stellenbosch: African Sun Media, 2017), 199-204. For memories of our common friend Russel Botman's similar logic of hope, see Dirk J. Smit, Om te leef asof nie. Meditasies opgedra aan Russel Botman (Wellington: BybelMedia, 2014); and "'Making History for the Coming Generation' - On the Theological Logic of Russel Botman's Commitment to Transformation." Stellenbosch Theological Journal Vol 1, no. 2 (2015): 607-632, DOI: http://dx.doi.org/10.17570/stj.2015.v1n2.a29.

61 See Douglas John Hall, When You Pray. Thinking Your Way into God's World (Valley Forge: Judson, 1987). See Dirk J. Smit, "Seeing Things Differently: On Prayer and Politics," in Lyn Holness \& Ralk Wüstenberg (eds), Theology in Dialogue. Essays in Honour of John W. de Gruchy (Cape Town: David Philip, 2002), 271-284. 
Beukes, Eugene et al., Tokkies. Reflections on Solidarity, with the moving subtitle Farewell to Unremembering: Commemorating the Faculty of Theology at The University of the Western Cape during the Struggle for Liberation (Belhar: LUS, 2020).

Bieler, André, The Social Humanism of Calvin (John Knox, 1964)

- Calvin's economic and social thought (Geneva: WARC, 2006).

Boesak, Allan, Kairos, Crisis, and Global Apartheid. The Challenge to Prophetic Resistance (New York: Palgrave Macmillan, 2015).

Boesak, Allan \& Curtiss Paul DeYoung, Radical Reconciliation. Beyond Political Pietism and Christian Quietism, (Maryknoll: Orbis, 2012).

Burrell, David B., Friendship and Ways to Truth (Notre Dame: University of Notre, 2000).

Burt, Donald X., Friendship and Society. An Introduction to Augustine's Practical Philosophy (Grand Rapids: Eerdmans, 1999).

Carmichael, Liz, Friendship. Interpreting Christian Love (London: T \& T Clark, 2004).

Carter, J. Kameron, Race. A Theological Account (New York: Oxford University, 2008).

Conradie, Ernst (ed), Reconciliation. A Guiding Vision for South Africa? (Stellenbosch: EFSA, 2013).

De Gruchy, John, Reconciliation. Restoring Justice (Minneapolis: Fortress, 2002).

De Lange, Frits, “The Event of Compassion," in Frits de Lange \& Juliana Claassens (eds), Considering Compassion. Global Ethics, Human

Dignity, and the Compassionate God (Eugene: Pickwick, 2018), 17-30.

Derrida, Jacques, Politics of Friendship (London: Verso, 1997).

Fiorenza, Francis Schüssler, "Prospects for Political Theology in the Face of Contemporary Challenges," in Michael Welker (ed), Political Theology: Contemporary Challenges and Future Directions (Louisville: Westminster John Knox, 2013), 37-60. 
Fukuyama, Francis, Identity. The Demand for Dignity and the Politics of Resentment (New York: Farrar, Straus, and Giroux, 2018).

Gellner, Ernest, Nations and Nationalism (Oxford: Blackwell, 1983).

Gerrish, Brian, "Tradition in the Modern World: The Reformed Habit of the Mind," in David Willis \& Michael Welker (eds), Toward the Future of Reformed Theology. Tasks, Topics, Traditions (Grand Rapids: Eerdmans, 1999), 3-20.

Griffioen, Sander \& René van Woudenberg, "We Must not Forget Those who are Absent. Interview with Karl-Otto Apel on the Universality of Ethics," in Sander Griffioen (ed.), What Right does Ethics have? Public Philosophy in a Pluralist Culture (Amsterdam: Vrije Universiteit Press, 1990), 11-21.

Grayling, A.C., Friendship (New Haven: Yale, 2013).

Grundlingh, Albert, Ruda Landman \& Nico Koopman (eds), Russel Botman. A Tribute 1953-2014 (Stellenbosch: African Sun Media, 2017), 199-204.

Hall, Douglas John, When You Pray. Thinking Your Way into God's World (Valley Forge: Judson, 1987).

Hastings, Adrian, The Construction of Nationhood. Ethnicity, Religion and Nationalism (Cambridge: Cambridge University, 2007).

Hobsbawm, Eric, Nations and Nationalism since 1780 (Cambridge: Cambridge University, 1990).

Jennings, Willie, The Christian Imagination. Theology and the Origins of Race (New Haven: Yale University, 2010).

Kendi, Ibram X., Stamped from the Beginning. The Definitive History of Racist Ideas in America (New York: Bold Type, 2016).

Hofheinz, Marco, Frank Mathwig \& Matthias Zeindler (eds), Freundschaft. Zur Aktualität eines traditionsreichen Begriffs (Zürich: Theologischer Verlag, 2014). 
Hume, Douglas A., Virtuous Friends. The New Testament, Greco-Roman Friendship Language, and Contemporary Community (Eugene: Cascade, 2019).

Konstan, David, Friendship in the Classical World (Cambridge: Cambridge University Press, 1997).

Koopman, Nico, God en die Lyding? ' $n$ Ondersoek na die ParadigmaTeorieë van A. van de Beek oor die Lydingsvraag (Bellville: University of the Western Cape, unpublished master's thesis, 1993).

- Dade of Deugde? Implikasies vir Suid-Afrikaanse Kerke van 'n ModernPostmoderne Debat oor die Moraliteit (Bellville: University of the Western Cape, unpublished dissertation, 2001).

- "Freedom of Religion and the Prophetic Role of the Church," NGTT Vol 43, no. 1 (2002): 237-247.

- “Trinitarian Anthropology, Ubuntu and Human Rights," in Russel Botman \& Karin Spörre (eds), Building a Human Rights Culture. South African and Swedish Perspectives (Falun: Stralins, 2003), 194-206.

- "Let the Plight of the Poor be Heard. Prophetic Speaking about Poverty Today." NGTT Vol 45, no. 2 Supplementum (2004): 440-451.

- "After Ten Years. Public Theology in Post-Apartheid South Africa." NGTT Vol 46 (2005): 149-164

- "Bonhoeffer's Anthropology and the Anthropology of Ubuntu," Nederlandse Theologische Tijdschrift (July 2005): 195-206.

- "Theology and the Fulfilment of Social and Economic Rights," in André van der Walt (ed), Theories of Social and Economic Justice (Stellenbosch: Sun Press, 2005), 128-140.

- "This is Who He is! Beyers Naudé - A Man of Virtue and Character," in Len Hansen (ed), The Legacy of Beyers Naudé (Stellenbosch: Sun Press, 2005), 153-168. 
- "Ubuntu is Not Enough. In Search of an Anthropology for Peaceful Living," in Dirk van Keulen \& Martien Brinkman (eds), Christian Faith and Violence. Studies in Reformed Theology Vol 10 (2005): 157171.

- "Contemporary Public Theology in the United States and South Africa. A Dialogue," in Drew Smith (ed.), Freedom's Distant Shores. American Protestants and Post-Colonial Alliances with America (Texas: Baylor, 2006), 209-222.

- "Curing or Caring? Some Theological Comments about Healing," Religion and Theology Vol 13 (2006): 38-53.

- "From Diverse and Apart to Diverse and Together. A Challenge of Rehumanization," in Eduardus van der Borght (ed), Affirming and Living with Differences, Studies in Reformed Theology Vol 12 (Leiden: Brill, 2006), 67-80.

— “Doing ethics in communion,” NGTT Vol 48 (2007): 366-375.

- “The Lord's Prayer - An Agenda for Christian Living." Journal for Reformed Theology Vol 1, no. 3 (2007): 1-4.

- "Public Theology in South Africa. A Trinitarian Approach." International Journal for Public Theology Vol 1, no. 2 (2007): 188-209.

- "Reconciliation and the Confession of Belhar 1986. Some Challenges for the URCSA.” NGTT Vol 48 (2007): 96-106.

- "Some Theological and Anthropological Perspectives on Human Dignity and Human Rights.” Scriptura 95 (2007): 177-185.

- "Towards a Human Rights Culture in South Africa. The Role of Moral Formation.” NGTT Vol 48 (2007): 107-118.

- "Christian Baptism and an Identity of Inclusivity, Dignity and Holiness," in Eduardus van der Borght (ed), Christian Identity, Studies in Reformed Theology Vol 16 (Leiden: Brill, 2008), 120-13.

- "Holiness and Public Life in South Africa: The Quest for Wholeness, Embrace and Justice." Colloquium 40, no. 2 (2008): 166-181. 
- "Towards Reconciliation and Justice in South Africa. Can Church Unity Make a Difference?" in Sebastian Kim, Pauline Kollontai \& Greg Hoyland (eds), Peace and Reconciliation. In Search of Shared Identity (Burlington: Ashgate, 2008), 95-108.

- "Vulnerable Church in a Vulnerable World? Towards an Ecclesiology of Vulnerability." Journal of Reformed Theology Vol 2, no. 3 (2008): 240-254.

— "For God So Loved the World ... Some Contours for Public Theology in South Africa," Stellenbosch University: Inaugural Lectures, March 2009.

- "Public Theology as Prophetic Theology. More than Utopianism and Criticism.” JTSA Vol 134 (2009): 117-130.

- "Public Theology in South Africa," in Ernst Conradie \& Christo Lombard (eds), Discerning God's Justice in Church, Society and Academy (Stellenbosch: Sun Press, 2009), 69-80.

- "Churches and Public Policy Discourses in South Africa." JTSA 136 (March 2010): 41-56.

- "John Calvin, Holiness and Public Life in Africa." NGTT Vol. 51 Supplementum (2010): 379-389.

— "Public Theology in Pluralistic Societies?" Verbum et Ecclesia 33, no. 2 (2012); “Some Contours for Public Theology," International Journal of Practical Theology Vol 14, no. 1 (2010): 123-138.

- "Belhar: A Transforming and Dignifying Tradition." JTSA Vol 139 (2011): 32-41.

- "Global Civil Society, Church Unity and World Unity," in William Storrar, Peter Casarella \& Paul Metzger (eds), A World for All? Global Civil Society in Political Theory and Trinitarian Theology (Grand Rapids: Eerdmans, 2011), 108-121.

- "Modes of Prophecy in a Democracy? in Heinrich Bedford-Strohm \& Etienne de Villiers (eds.), Prophetic Witness. An Appropriate Contemporary Mode of Public Discourse? (Berlin: Lit Verlag, 2011), 181-192. 
- "The Common Good and Human Dignity - Some Very Preliminary Remarks," NGTT Vol 53, no. 2 (2012): 31-40.

— "Public Theology in a Suffering World?," in Eduardus van der Borght \& Paul van Geest (eds), Strangers and Pilgrims on Earth: Essays in Honour of Abraham van de Beek (Leiden: Brill, 2012), 887-895.

- "Towards the Fulfilment of Three Generations of Rights: A Theological Contribution by Koos Vorster." In die Skriflig Vol 46, no. 1 (2012), \#a.45

- "Towards a Pedagogy of Hybridity, Reconciliation and Justice," in Brenda Leibowitz (ed), Higher Education for the Public Good (Stellenbosch: Sun Press, 2012), 151-163.

- "A Prophet for Dignity? A Theological Perspective." Tydskrif vir Letterkunde Vol 49, no. 1 (2012): 5-15.

- "Churches and Moral Formation in Public Life? The Story of the Ethical Leadership Project in the Western Cape." Theologia Viatorum 37, no. 1 (2013): 108-122.

- "Hope, Vulnerability and Disability? A Theological Perspective, in Julie Claassens, Leslie Swartz \& Len Hansen (eds), Searching for Dignity: Conversations on Human Dignity, Theology and Disability (Stellenbosch: Sun Press, 2013), 43-54.

- "Human Dignity in Africa: A Christological Approach," Scriptura, Vol 104, no. 6 (2013): 240-249.

- "Theological Education for Dignity in Africa - a Public Theological Perspective," in Isabel Phiri \& Dietrich Werner (eds), Handbook of Theological Education in Africa (Geneva: WCC, 2013), 698-706.

- "A Theology of Interpathy and Dignity," in James Cochrane, Elias Bongmba, Isabel Phiri, Des van der Water (eds), Living on the Edge. Essays in Honour of Steve de Gruchy (Pietermaritzburg: Cluster, 2013), $128-138$.

- Cries for a Humane Life. Reflections on the Lord's Prayer (Wellington: Bible Media, 2014). 
- "Inclusive dignity and land reform in South Africa," Scriptura Vol 113 (2014): 1-8.

- "Prayer and the Transformation of Public Life in South Africa." Interpretation Vol 68, no. 1 (2014): 54-65.

- "Prophecy and Democracy? Some Arguments in Favour of Prophetic Discourse in Civilizing Democratic Societies," in Pieter Vos \& Onno Zijlstra (eds), The Law of God. Exploring God and Civilization (Leiden: Brill, 2014), 239-255.

- "Public Theology and the Public Role of Churches in South Africa today," in Allan Cole (ed.), Theology in Service to the Church (Eugene: Wipf \& Stock, 2014), 139-152.

- "Tasting the Communion of the Spirit? Reflections on a Decade-long Journey of Embrace," in Lutzen Miedema \& Simon Ririhena (eds.), The Calling of the Church (Stellenbosch: Sun Media, 2014), 91-101.

- "Theology and the Building of Civilising Democracy in South Africa." NGTT Vol 55 (2014): 625-639.

- "Uniting for Unity, Reconciliation and Justice. The Uniting Reformed Church in Southern Africa," in Leo Koffeman (ed), The Protestant Church in The Netherlands: Church Unity in the 21st Century (Berlin: Lit Verlag, 2014), 100-110.

- "Citizenship in South Africa Today. Some Insights from Christian Ecclesiology.” Missionalia Vol 43, no. 3 (2015): 425-437.

— "Human Dignity, Human Rights and Socio-Economic Exclusion?," in Wilhelm Gräb \& Lars Charbonnier (eds), Religion and Human Rights. Global Challenges from Intercultural Perspectives (Berlin: De Gruyter, 2015), 131-148.

- "Men and Women in Church and Society. Equal in Dignity? United in Diversity?" in Elna Mouton, Gertrude Kapuma, Len Hansen \& Thomas Togom (eds), Living with Dignity: African Perspectives on Gender Equality (Stellenbosch: Sun Media, 2015), 19-32. 
- "In Search of a Transforming Public Theology: Drinking from the Wells of Black Theology," in Drew Smith, William Ackah, Anthony Reddie \& Rotney Tshaka (eds.), Contesting Post-Racialism. Conflicted Churches in the United States and South Africa (Jackson: University of Mississippi, 2015), 211-225.

- “Adam Small se Transformerende Afrikaans," in Wannie Carstens \& Michael le Cordeur (eds), Ons Kom van Vêr: Bydraes oor Bruin Afrikaanssprekendes se Rol in die Ontwikkeling van Afrikaans (Tygervallei: Naledi, 2016), 539-551.

- "Public Theology in African Churches," in Isabel Apawo Phiri, Kennedy Owino, Dietrich Werner \& Chammah Judex Kaunda (eds.), Anthology of African Christianity (Oxford: Regnum, 2016), 1142-1148.

- "Public Theology and the Plight of Children in Africa," in Jan Grobbelaar \& Gert Breed (eds.) Welcoming Africa's Children Theological and Ministry Perspectives (Durbanville: Aosis, 2016), 193-209.

- "An Active South African Civil Society for the Common Good, in Koos Vorster, Michael Welker \& Nico Koopman (eds), Church and Civil Society: German and South African Perspectives (Stellenbosch: Sun Press, 2017), 369-384.

— "Public Theology in the Context of Nationalist Ideologies: A South African Example," in Sebastian Kim \& Katie Day (eds.) A Companion to Public Theology (Leiden: Brill, 2017), 150-163.

- "On Leadership in Vulnerability," in Jeremy Punt \& Marius Nel (eds), Reading Writing Right: Essays presented in honour of Prof Elna Mouton (Stellenbosch: African Sun Media, 2018), 249-260.

— "Envision and Criticize: Doing Public Theology When Democracy Seems to Fail." International Journal of Public Theology Vol 13, no. 1 (2019): 94-108.

- "Bonhoeffer and the Future of Public Theology in South Africa. The Ongoing Quest for Life Together," in Robert Vosloo \& Nico Koopman, in Reading Bonhoeffer in South Africa after the Transition to Democracy: Selected Essays (Berlin: Peter Lang, 2020), 85-96. 
— "Bonhoeffer in Harlem: Some Lessons for Contemporary South Africa," in Robert Vosloo \& Nico Koopman, in Reading Bonhoeffer in South Africa after the Transition to Democracy: Selected Essays (Berlin: Peter Lang, 2020), 151-162.

Koopman, Nico \& Robert Vosloo, Die Ligtheid van die Lig. Morele Oriëntasie in 'n Postmoderne Tyd (Wellington: Lux Verbi.BM, 2002).

Kort, Wesley, Bound to Differ (University Park: Pennsylvania State University, 1992).

Maluleke, Tinyiko, “The Elusive Public of Public Theology.” International Journal of Public Theology 5 (2011): 79-89.

— "Why I am not a Public Theologian." Ecumenical Review Vol 72, no. 2 (2021): 297-315.

Mbembe, Achille, Necropolitics (Durham: Duke University, 2019).

Mehring, Reinhard, Carl Schmitt. Aufstieg und Fall. Eine Biographie (München: Verlag C.H. Beck, 2009).

Meier, Heinrich, The Lesson of Carl Schmitt. Expanded Edition (Chicago: The University of Chicago, 2011).

Meilaender, Gilbert C., Friendship. A Study in Theological Ethics (Notre Dame: University of Notre Dame, 1981).

Miller, Richard, Friends and Other Strangers. Studies in Religion, Ethics, and Culture (New York: Columbia University, 2016).

Nehamas, Alexander, On Friendship (New York: Basic Books, 2016).

Nixon, Jon, Hannah Arendt and the Politics of Friendship (London: Bloomsbury, 2015).

Nürnberger, Klaus \& John Tooke (eds), The Cost of Reconciliation in South Africa (Cape Town: Methodist Publishing House, 1988).

Nussbaum, Martha C., The Cosmopolitan Tradition. A Noble but Flawed Ideal (Cambridge, Belknap, 2019).

O'Donovan, Oliver, The Problem of Self-Love in Augustine (New Haven: Yale, 1980). 
- The Desire of the Nations. Rediscovering the Roots of Political Theology (Cambridge: Cambridge University, 1999).

- Common Objects of Love. Moral Reflection and the Shaping of

Community (Grand Rapids: Eerdmans, 2002).

- Bonds of Imperfection. Christian Politics Past and Present (Grand Rapids: Eerdmans, 2004).

- The Ways of Judgment (Grand Rapids: Eerdmans, 2005).

Pakaluk, Michael, Other Selves. Philosophers on Friendship (Indianapolis: Hackett, 1991).

Rouner, Leroy S. (ed), The Changing Face of Friendship (Notre Dame: University of Notre Dame, 1994).

Schmitt, Carl, Political Theology. Four Chapters on the Concept of Sovereignty (Cambridge: MIT, 1985).

Small, Adam, Kitaar My Kruis (Kaapstad: HAUM, 1974).

Smit, Dirk J., "Seeing Things Differently: On Prayer and Politics," in Lyn Holness \& Ralk Wüstenberg (eds), Theology in Dialogue. Essays in Honour of John W. de Gruchy (Cape Town: David Philip, 2002), 271-284.

— "On Self-love. Impulses from Calvin and Calvinism for Life in Society?" in Essays on Being Reformed. Collected Essays 3, ed. RR Vosloo (Stellenbosch: Sun Press, 2009), 493-512.

- Om te leef asof nie. Meditasies opgedra aan Russel Botman (Wellington: Bybel-Media, 2014).

- “Making History for the Coming Generation' - On the Theological Logic of Russel Botman's Commitment to Transformation." Stellenbosch Theological Journal Vol 1, no. 2 (2015): 607-632.

- "Living with Strangers? On Constructing Ethical Discourses," in Daniel Pedersen \& Christopher Liley (eds.), Human Origins and the Image of God: Essays in Honour of J. Wentzel van Huysteen (Grand Rapids: Eerdmans, 2017), 273-313. 
- "Justice as/and Compassion? On the Good Samaritan and Political Theology," in Frits de Lange \& Juliana Claassens (eds), Considering Compassion. Global Ethics, Human Dignity, and the Compassionate God (Eugene: Pickwick, 2018), 109-128.

Taubes, Jacob, The Political Theology of Paul (Stanford: Stanford University Press, 2004).

Taylor, Mark L., The Theopolitical and the Political. On the Weight of the World (Minneapolis: Fortress, 2011).

Vorster, Willem S. (ed), Reconciliation and Construction (Pretoria; UNISA, 1986).

Von Heyking, John \& Richard Avramenko (eds), Friendship \& Politics. Essays in Political Thought (Notre Dame: University of Notre Dame, 2008).

Wadell, Paul J., Friendship and the Moral Life (Notre Dame: University of Notre Dame, 1989).

- Becoming Friends. Worship, Justice, and the Practice of Christian

Friendship (Grand Rapids: Brazos, 2002). 